\title{
Results from two sets of experiments with spring barley, the first comparing injected with broadcast nitrogen granules, the second comparing injected and combine-drilled NPK solutions with broadcast NPK granules
}

\author{
By F. V. WIDDOWSON ANd A. PENNY \\ Rothamsted Experimental Station, Harpenden, Herts.
}

(Received 13 April 1976)

\begin{abstract}
SUMMARY
Six experiments from 1969-71 compared yields of, percentages of $\mathrm{N}$ in, and removals of $\mathrm{N}$ by barley given 63 or $126 \mathrm{~kg} \mathrm{~N} /$ ha either as urea or as 'Nitro-Chalk' which were either broadcast or injected into the seed bed. Both fertilizers were equally effective and each gave a slightly larger yield when injected.

Eleven more experiments compared yields of, percentages of $\mathrm{N}$ in, and removals of $\mathrm{N}$ by barley given either NPK solution fertilizers or NPK granules supplying 63 or $126 \mathrm{~kg} \mathrm{~N} / \mathrm{ha}$. One liquid (14-6-8) supplied the whole of the $\mathrm{N}$ and was either sprayed, combine-drilled or injected mid-way between the seed rows $(15 \mathrm{~cm}$ apart). The other liquid (4-10-10) supplied one-fifth of the $N$ and was either combine-drilled or injected; 'Nitro-Chalk' supplied the remainder of the $\mathrm{N}$. The granular fertilizer $(20-10-10)$ was broadcast.

The 14-6-8 solution always gave a smaller yield than comparable granules. Yields with injected dressings were no larger than with sprays, but each was safe. Combinedrilled dressings were harmful and often killed the barley and decreased yields especially when $126 \mathrm{~kg} \mathrm{~N} / \mathrm{ha}$ was given.

The 4-10-10 solution was harmless when combine-drilled and gave a larger yield than the granules when $63 \mathrm{~kg} \mathrm{~N} / \mathrm{ha}$ was given and the same yield when $126 \mathrm{~kg} N / \mathrm{ha}$ was given. It gave a smaller yield than the granules when it was injected.

Grain percentage $\mathbf{N}$ tended to be larger with the injected liquids and smaller with the sprays than with the broadcast granules though the amount of $N$ recovered by the barley from the injected liquids was no larger than from the granules.
\end{abstract}

\section{INTRODUCTION}

Kahari \& Elonen (1969) made experiments with barley on two clay soils in South Finland, an area subject to spring and early summer droughts. Both roots and shoots grew more quickly, and hence were larger, where the NPK fertilizer that they used was placed $8 \mathrm{~cm}$ deep, mid-way between the rows, than when it was broadcast. They obtained a strong positive correlation between the weight of roots and the yield of grain and concluded that "it is important to place the fertilizer at a convenient depth, 5-10 cm, when cereals are in question. The horizontal distance between seedrows and ferti. lized rows appears to be of less importance'.

Dam Kofoed \& Larsen (1971) compared alternative methods of applying urea for spring cereals. They confirmed that urea and seed should be sown separately, not together, to prevent damage to the germinating seeds and also that broadcast urea should be worked into the soil to minimize the risk of loss of ammonia to the atmosphere as it hydrolysed. However, their mean yields (from 11 experiments) did not differ significantly with method of application.

Widdowson, Penny \& Flint (1972) showed that an aqueous solution of urea injected into the seed bed was slightly more effective for spring barley, when judged by yield or by $\mathrm{N}$ recovery, than ammonium nitrate/limestone granules $(21 \% \mathrm{~N})$ broadcast over the seed bed. However, an NPK liquid fertilizer rich in urea was less effective when sprayed and more damaging when combine-drilled than a comparable granular NPK fertilizer (which contained most of its nitrogen as ammonium nitrate).

Liquid fertilizers not only save labour but also facilitate placement, because they can be pumped 
under pressure into bands which the young roots can easily reach and hence readily take up the nutrients in them. Consequently, the experiments that we had begun in 1969 to value injected $N$ for spring barley were extended to assess whether (1) liquid NPK fertilizers rich in urea could be injected safely between rows of barley, and (2) whether this technique would give increased yields under our conditions, as had been shown in Finland. This paper gives results from both sets of experiments.

\section{METHOD}

\section{Experiments with nitrogen fertilizers}

Two were made in 1969, in 1970 and in 1971 to compare injected and broadcast dressings of urea $(46 \% \mathrm{~N}$ ) and 'Nitro-Chalk' (ammonium nitratel limestone) $(21 \% \mathrm{~N})$. Each fertilizer was applied to give 63 or $126 \mathrm{~kg} \mathrm{~N} /$ ha. These eight fertilizer treatments plus two plots not receiving nitrogen were arranged in four randomized blocks. Each year one experiment was at Rothamsted (clay loam over Clay-with-Flints) and one at Woburn (sandy loam over Lower Greensand).

In 1969 both fertilizers were injected into the plough furrows in bands $14 \mathrm{~cm}$ apart and $7-10 \mathrm{~cm}$ deep with a Tume fertilizer drill fitted with a crumbler. In 1970 and 1971 a Fiona cultivator drill was used to inject the fertilizer in bands $15 \mathrm{~cm}$ apart and 8-10 cm deep into the seed bed. Equivalent broadcast dressings were applied by hand. Additionally, in 1971 only, an aqueous solution of urea $(19 \% \mathrm{~N})$ was either injected in bands $30 \mathrm{~cm}$ apart and 8-10 cm deep, or sprayed over the seed bed. Individual plots were $2.1 \mathrm{~m}$ wide and $30 \mathrm{~m}$ long. Basal $P$ and $K(250 \mathrm{~kg} / \mathrm{ha}$ of $0-20-20)$ was combine-drilled in 1969 and broadcast in 1970 and 1971.

We grew Zephyr barley in 1969 and Julia in 1970 and 1971. In 1969 there was little lodging at Rothamsted, but barley given $126 \mathrm{~kg} \mathrm{~N} /$ ha lodged at Woburn. In 1970 there was no lodging at either farm, nor in 1971 at Rothamsted, but in 1971 at Woburn the barley lodged in June and yielded less with $126 \mathrm{~kg} \mathrm{~N} / \mathrm{ha}$ than with none (this field had been ploughed out of grass in 1962). At harvest the plots were combine-harvested and the grain weighed and sampled for dry-matter and nitrogen content.

\section{Experiments with liquid NPK fertilizers}

There were three in 1971 and four in 1972 and 1973 , all on private farms. Each year two liquid fertilizers were used. The first supplied the whole

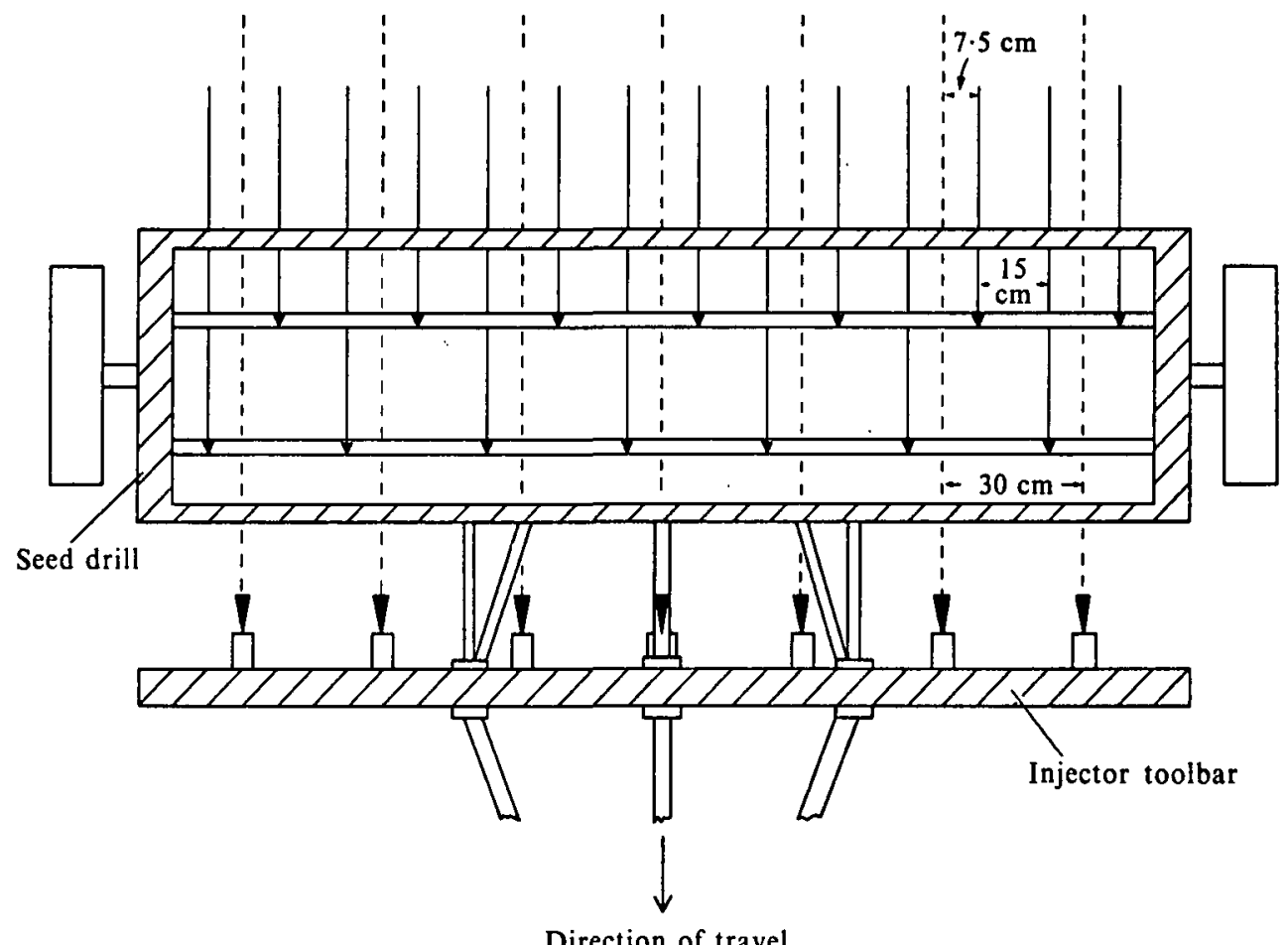

Fig. 1. The relationship between the bands of fertilizer and the rows of seed, in the trials rig made for the barley experiments with liquid fertilizers in 1972 and $1973 . \rightarrow-\rightarrow$, bands of injected fertilizer and fertilizer knives; $\longrightarrow$, rows of seed and seed tines. 
of the $\mathrm{N}$ given to the barley; it contained $14 \% \mathrm{~N}$, $6 \% \mathrm{P}_{2} \mathrm{O}_{5}$ and $8 \% \mathrm{~K}_{2} \mathrm{O}$ (subsequently referred to as 14-6-8). The second supplied only one-fifth of the $\mathrm{N}$ given; it contained $4 \% \mathrm{~N}, 10 \% \mathrm{P}_{2} \mathrm{O}_{5}$ and $10 \% \mathrm{~K}_{2} \mathrm{O}$ (4-10-10). The balance (four-fifths) of this $\mathrm{N}$ was broadcast as 'Nitro-Chalk' $(21 \% \mathrm{~N})$ at sowing. Yields with each liquid fertilizer were compared with those from a granular NPK fertilizer containing $20 \% \mathrm{~N}, 10 \% \mathrm{P}_{2} \mathrm{O}_{5}$ and $10 \% \mathrm{~K}_{2} \mathrm{O}$ (20-10-10) broadcast over the seed bed. This contrast is complicated by the fact that the 14-6-8 liquid fertilizer was rich in urea (roughly $80 \%$ of its $\mathrm{N}$ content) and that both it and the 4-10-10 were based on di-ammonium phosphate. The 20-10-10 granules contained $\mathrm{N}$ mostly in the form of ammonium nitrate and were based on mono-ammonium phosphate. The techniques and methods of application were not consistent throughout.

In 1971 each of the liquid fertilizers was either injected in bands $30 \mathrm{~cm}$ apart and $8-10 \mathrm{~cm}$ deep as a separate operation before the seed was sown, or combine-drilled with the seed in rows $17.5 \mathrm{~cm}$ apart. The granular 20-10-10 was either broadcast or combine-drilled, using the same drill. The 'Nitro-Chalk' was broadcast immediately after sowing. All the fertilizers were applied to give either 63 or $126 \mathrm{~kg} \mathrm{~N} /$ ha. These 12 treatments plus two unmanured plots were arranged in four randomized blocks in each experiment. Individual plots were $2.1 \mathrm{~m}$ wide and $20.1 \mathrm{~m}$ long. Julia barley was sown at Gaddesden (Flinty-head and rain wash) on 11 March and at Eversholt (sandy drift over clay) on 29 March, and Deba Abed at Wheathampstead (clay loam over Clay-with-Flints) on 30 March. Combine-drilling the liquid 14-6-8 checked early growth at Eversholt and Wheathampstead but not at Gaddesden, where rain followed sowing. All barley given $\mathrm{N}$ lodged at Eversholt and Wheathampstead, but only that given $126 \mathrm{~kg} \mathrm{~N} /$ ha at Gaddesden. The centre eight rows were combine-harvested and the grain weighed and sampled for dry matter and nitrogen determinations.

In 1972 the liquid fertilizer injector was adapted so that the liquid fertilizers could be injected simultaneously with sowing, in bands positioned mid-way between the rows of seed (Fig. 1). A six-point linkage allowed us to fasten a Fiona cultivator drill sowing seed in rows $15 \mathrm{~cm}$ apart directly behind the injector. A small stainless-steel tube was welded to the back of each seed tine so that the liquid fertilizers could be pumped directly into the seed row (contact placement) and thus combine-drilled. Also a spray boom was fastened to the front of the drill so that the 14-6-8 fertilizer could be sprayed in the path of the seed tines. The

Table 1. Visual estimates of early growth (unmanured barley $=100$ ) from two amounts of one granular and two liquid fertilizers applied in several ways

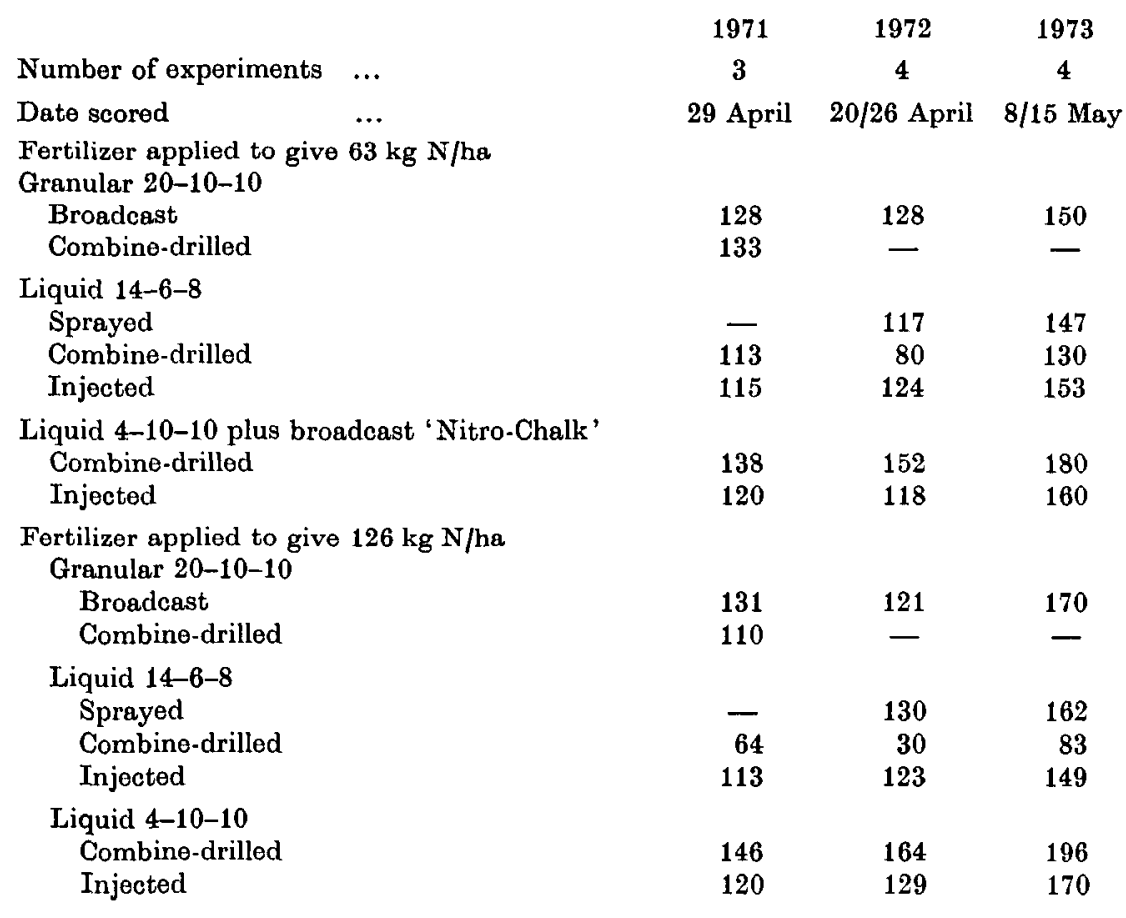


test of combine-drilled granular 20-10-10 was no longer feasible and so the broadcast test became the standard. The 12 fertilized plots plus two not given fertilizer were again arranged in four randomized blocks. Vada barley was sown at Gaddes. den on 17 March, Zephyr at Barton Hill (thin Flinty-head over Chalk) on 20 March, Julia at Eversholt on 21 March and Deba Abed at Wheathampstead on 22 March. Combine-drilling the 14-6-8 liquid fertilizer again checked early growth especially when $126 \mathrm{~kg} \mathrm{~N} / \mathrm{ha}$ was given (Table 1). At Eversholt (which has sandy soil) this amount of this fertilizer killed most of the barley plants and these plots had to be resown. The damage was less severe elsewhere. By contrast combinedrilled 4-10-10 improved early growth. At harvest, lodging occurred on all the manured plots at Gaddesden and Eversholt and with $126 \mathrm{~kg} \mathrm{~N} / \mathrm{ha}$ at Barton Hill. There was none at Wheathampstead.

In 1973 the experiments were repeated unchanged. Zephyr barley was sown at Barton Hill on 9 March, Julia at Eversholt on 14 March, Deba Abed at Wheathampstead on 15 March and at
Hexton (chalky downwash over Gault clay) on 19 March. The combine-drilled 14-6-8 again checked early growth, severely at Eversholt, whilst combine-drilled 4-10-10 improved it.

Thunderstorms during July caused extensive lodging at Wheathampstead and Hexton and severe lodging at Eversholt, where a grazed ley had been ploughed for oats in 1972 .

\section{RESULTS}

\section{Experiments with nitrogen fertilizers}

Appendix Table 1 shows yields in individual experiments. Yield differed little with method of application, though the injected $\mathrm{N}$ tended to give the larger yield (Table 2). The benefit from injecting the $\mathrm{N}$, though small, was consistent, for it gave the larger yield in 19 of 24 comparisons and was as large with 'Nitro-Chalk' as with urea. Percentage $\mathrm{N}$ in the barley grain was not changed by injecting either fertilizer (Appendix Table 2), though it was greatly increased by giving the barley 126 rather than $63 \mathrm{~kg} \mathrm{~N} /$ ha (Table 2). The largest variations

Table 2. Mean yields of, percentages of $N$ in, and amounts of $N$ removed by, barley grown in six experiments comparing injected and broadcast dressings of urea and 'Nitro-Chalk', 1969-71

\begin{tabular}{|c|c|c|c|}
\hline & \multicolumn{2}{|c|}{ Nitrogen fertilizer } & \multirow{2}{*}{$\begin{array}{c}\text { Number of } \\
\text { occasions } \\
\text { (maximum } 6 \text { ) } \\
\text { when injected } \\
N \text { was the } \\
\text { better }\end{array}$} \\
\hline & Broadcast & Injected & \\
\hline & \multicolumn{3}{|c|}{ Yield of grain (t/ha at $85 \%$ D.Mr.) } \\
\hline Without nitrogen & \multicolumn{2}{|c|}{$3 \cdot 61$} & \\
\hline $\begin{array}{l}\text { With } 63 \mathrm{~kg} \mathrm{~N} / \mathrm{ha} \text { as } \\
\text { 'Nitro-Chalk' } \\
\text { Urea }\end{array}$ & $\begin{array}{l}5 \cdot 10 \\
5 \cdot 13\end{array}$ & $\begin{array}{l}5 \cdot 18 \\
5 \cdot 29\end{array}$ & $\begin{array}{l}5 \\
5\end{array}$ \\
\hline \multicolumn{4}{|l|}{ With $126 \mathrm{~kg} \mathrm{~N} / \mathrm{ha}$ as } \\
\hline $\begin{array}{l}\text { 'Nitro-Chalk' } \\
\text { Urea }\end{array}$ & $\begin{array}{l}5 \cdot 18 \\
5 \cdot 23\end{array}$ & $\begin{array}{l}5 \cdot 34 \\
5 \cdot 23\end{array}$ & $\begin{array}{l}6 \\
3\end{array}$ \\
\hline \multicolumn{4}{|c|}{ Percentage $\mathrm{N}$ in grain } \\
\hline Without nitrogen & & & \\
\hline $\begin{array}{l}\text { With } 63 \mathrm{~kg} \mathrm{~N} / \mathrm{ha} \text { as } \\
\text { 'Nitro.Chalk' } \\
\text { Urea }\end{array}$ & $\begin{array}{l}1.54 \\
1.57\end{array}$ & $\begin{array}{l}1.55 \\
1.56\end{array}$ & $\begin{array}{l}3 \\
2\end{array}$ \\
\hline $\begin{array}{l}\text { With } 126 \mathrm{~kg} \text { N/ha as } \\
\text { 'Nitro-Chalk' } \\
\text { Urea }\end{array}$ & $\begin{array}{l}1 \cdot 90 \\
1 \cdot 83\end{array}$ & $\begin{array}{l}1.86 \\
1.88\end{array}$ & $\begin{array}{l}2 \\
3\end{array}$ \\
\hline \multicolumn{4}{|c|}{$N(\mathrm{~kg} / \mathrm{ha})$ removed by grain } \\
\hline Without nitrogen & & & \\
\hline $\begin{array}{l}\text { With } 63 \mathrm{~kg} \mathrm{~N} / \mathrm{ha} \text { as } \\
\text { 'Nitro-Chalk' } \\
\text { Urea }\end{array}$ & $\begin{array}{l}67.1 \\
68.9\end{array}$ & $\begin{array}{l}68 \cdot 7 \\
69 \cdot 9\end{array}$ & $\begin{array}{l}4 \\
4\end{array}$ \\
\hline $\begin{array}{l}\text { With } 126 \mathrm{~kg} \mathrm{~N} / \mathrm{ha} \text { as } \\
\text { 'Nitro-Chalk' } \\
\text { Urea }\end{array}$ & $\begin{array}{l}82.5 \\
80.8\end{array}$ & $\begin{array}{l}83 \cdot 6 \\
82 \cdot 8\end{array}$ & $\begin{array}{l}4 \\
3\end{array}$ \\
\hline
\end{tabular}


in $\% \mathrm{~N}$ were caused by season and by site. Grain containing more than $2 \% \mathrm{~N}$ was produced by barley given $126 \mathrm{~kg} \mathrm{~N} /$ ha at three of the six sites.

\section{Experiments with liquid NPK fertilizers}

Appendix Table 3 shows yields in each experiment. Yields were greatly increased by both amounts of fertilizer at each centre except Ever. sholt where the barley was grown in fields which had been grazed by dairy cattle 2 or 3 years previously. The other sites were on farms which grew only arable crops, mainly cereals, hence the large responses to fertilizer there. Combine-drilled 4-10-10 gave a significantly larger yield than broadcast 20-10-10 on the chalky soils at Barton Hill (in 1972 and 1973), but not elsewhere.

Table 3 shows that the 14-6-8 liquid fertilizer rich in urea usually gave a smaller yield than granules supplying comparable amounts of $N, P$ and $K$ whether it was sprayed, or injected or combine-drilled. The risks from combine-drilling fertilizers rich in urea were amply confirmed, for the 14-6-8 fertilizer, combine-drilled at $126 \mathrm{~kg} \mathrm{~N} / \mathrm{ha}$, gave significantly smaller yields than broadcast granules, in 5 of the 11 experiments. By contrast the 4-10-10 liquid, which contained little urea and supplied only one-fifth as much $N$, improved establishment when combine-drilled and was the only treatment involving liquid fertilizers which produced a significantly larger yield than broadcast granules did (in two of the 11 experiments). Although 14-6-8 was perfectly safe when it was injected mid-way between the rows of barley, subsequent growth was no better than when it was sprayed over the seed bed and yields from the two methods of application were similar. The proposition that the phosphate in the injected 14-6-8 fertilizer was too far away from the seed row to benefit the young seedlings was confirmed by the fact that growth on plots given injected 4-10-10 was inferior to that on plots given combine-drilled 4-10-10.

Table 4 shows that the sole benefit of injecting the 14-6-8 fertilizer was to limit the loss in yield that it caused when the double amount of it was combine-drilled. By contrast the 4-10-10 liquid

Table 3. Mean yields ( $t /$ ha at $85 \%$ D.M.) of barley grain each year, in experiments comparing alternative methods of applying liquid fertilizers in 1971-73

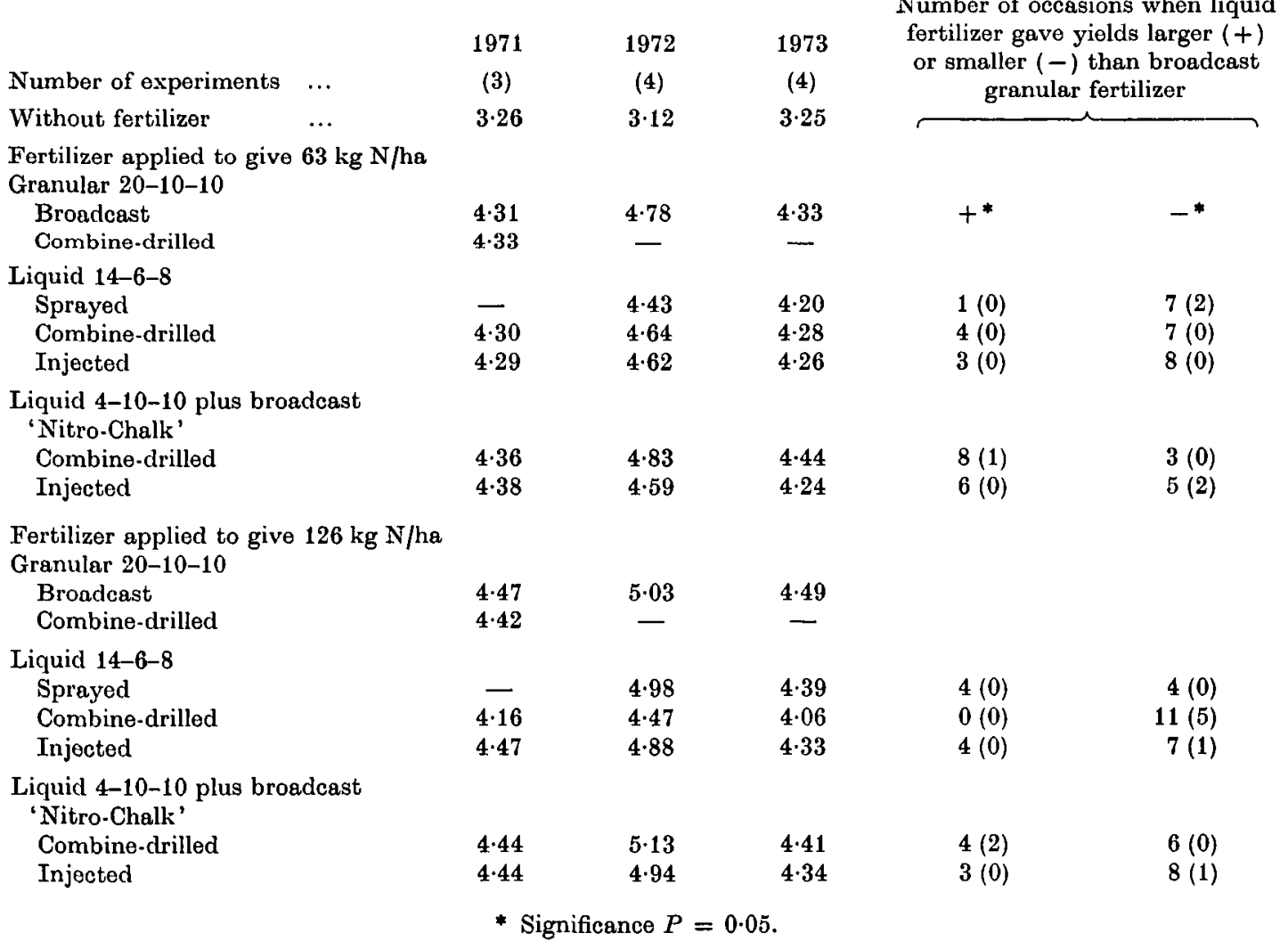


Table 4. Mean yields (t/ha at $85 \%$ D.M.) of barley grain without and with fertilizer, the mean increase in yield from each fertilizer treatment and the increases from the liquid fertilizers expressed as a percentage of that from broadcast granular fertilizer $(=100)$ in 11 experiments, 1971-73

\begin{tabular}{|c|c|c|c|}
\hline & Total yield & $\begin{array}{l}\text { Increases from } \\
\text { fertilizers }\end{array}$ & $\begin{array}{l}\text { Percentage } \\
\text { equivalence } \\
\text { of increases }\end{array}$ \\
\hline Without fertilizer $\quad \ldots$ & $3 \cdot 21$ & - & - \\
\hline $\begin{array}{l}\text { Fertilizer applied to giv } \\
\text { Granular } 20-10-10\end{array}$ & $4 \cdot 49$ & $1 \cdot 28$ & 100 \\
\hline $\begin{array}{l}\text { Liquid 14-6-8 } \\
\text { Combine-drilled } \\
\text { Injected }\end{array}$ & $\begin{array}{l}4 \cdot 41 \\
4 \cdot 39\end{array}$ & $\begin{array}{l}1 \cdot 20 \\
1 \cdot 18\end{array}$ & $\begin{array}{l}93 \cdot 8 \\
92 \cdot 2\end{array}$ \\
\hline $\begin{array}{l}\text { Liquid 4-10-10 plus } \\
\text { Combine-drilled } \\
\text { Injected }\end{array}$ & $\begin{array}{l}4 \cdot 56 \\
4 \cdot 40\end{array}$ & $\begin{array}{l}1 \cdot 35 \\
1 \cdot 19\end{array}$ & $\begin{array}{r}105 \cdot 5 \\
93 \cdot 0\end{array}$ \\
\hline $\begin{array}{l}\text { Fertilizer applied to giv } \\
\text { Granular } 20-10-10\end{array}$ & $4 \cdot 68$ & $1 \cdot 47$ & 100 \\
\hline $\begin{array}{l}\text { Liquid 14-6-8 } \\
\text { Combine-drilled } \\
\text { Injected }\end{array}$ & $\begin{array}{l}4 \cdot 24 \\
4 \cdot 57\end{array}$ & $\begin{array}{l}1 \cdot 03 \\
1 \cdot 36\end{array}$ & $\begin{array}{l}70 \cdot 1 \\
92 \cdot 5\end{array}$ \\
\hline $\begin{array}{l}\text { Liquid 4-10-10 plus } \\
\text { Combine-drilled } \\
\text { Injected }\end{array}$ & $\begin{array}{l}4 \cdot 68 \\
4 \cdot 59\end{array}$ & $\begin{array}{l}1 \cdot 47 \\
1 \cdot 38\end{array}$ & $\begin{array}{c}100 \\
93.9\end{array}$ \\
\hline
\end{tabular}

Table 5. Mean percentages of $N$ in barley grain, each year, in 11 experiments comparing alternative methods of applying liquid fertilizers, 1971-73

Number of experiments $\quad \ldots$

Without fertilizer $\cdots$

Fertilizer applied to give $63 \mathrm{~kg} \mathrm{~N} / \mathrm{ha}$

Granular 20-10-10

Broadcast

Combine-drilled

Liquid 14-6-8

Sprayed

Combine-drilled

Injected

Liquid 4-10-10 plus broadcast 'Nitro-Chalk'

Combine-drilled

Injected

Fertilizer applied to give $126 \mathrm{~kg} \mathrm{~N} / \mathrm{ha}$

Granular 20-10-10

Broadcast

Combine-drilled

Liquid 14-6-8

Sprayed

Combine-drilled

Injected

Liquid 4-10-10 plus broadcast 'Nitro-Chalk' Combine-drilled

Injected
1.42

$1 \cdot 50$

1.51

$\overline{1 \cdot 47}$

1.53

1.46

1.52

$1 \cdot 64$

1.70

1972

(4)

1973

(4)

1.44

1.51

$1 \cdot 46$

$1 \cdot 51$

$1 \cdot 72$

1.58

\section{7}

1.56
1.52

1.58

$1 \cdot 66$

1.71

$1 \cdot 68$

1.57

1.60

1.69

1.57

1.53

1.69

1.59

$1 \cdot 52$

$1 \cdot 71$

1.86

1.98

1.84

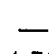

$1 \cdot 76$

$1 \cdot 70$

1.92

$1 \cdot 91$

2. 01

1.89

$1 \cdot 72$

$1 \cdot 90$

2.01

$1 \cdot 89$

$1 \cdot 69$

$1 \cdot 80$

$2 \cdot 00$

1.84

$1 \cdot 71$

1.90

$2 \cdot 06$

1.91 
Table 6. Mean amounts ( $\mathrm{kg} / \mathrm{ha}$ ) of $\mathrm{N}$ removed by barley grain, each year, in 11 experiments comparing alternative methods of applying liquid fertilizers, 1971-73

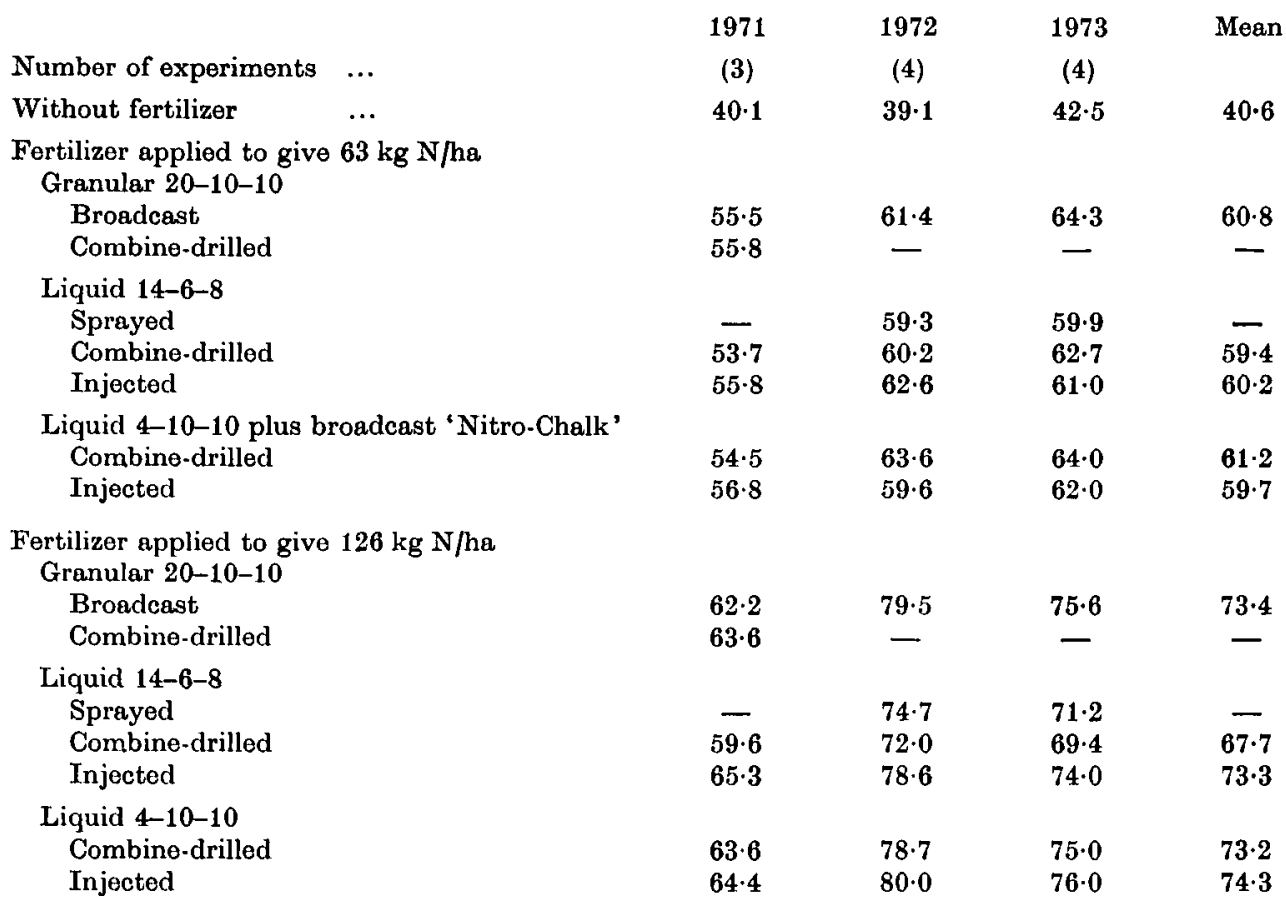

was always better combine-drilled than injected, though this technique produced a larger yield than the broadcast granules only when the single amount (63 $\mathrm{kg} \mathrm{kg} \mathrm{N/ha)} \mathrm{was} \mathrm{given.}$

Appendix Table 4 shows percentages of $\mathbf{N}$ in the grain at each centre. Each year grain from the Eversholt site contained the most $N$ and this was increased further both by the single and by the double amounts of $\mathrm{N}$, whether or not they also increased yield. Grain percentage $\mathrm{N}$ was increased a little by 63 and greatly by $126 \mathrm{~kg} \mathrm{~N} / \mathrm{ha}$ at all the other sites. Four of the sites produced grain containing more than $2 \% \mathrm{~N}$ when $126 \mathrm{~kg} \mathrm{~N} /$ ha was given.

Table 5 shows that there was no consistent difference in grain nitrogen content between barley manured with liquid or with granular fertilizer. Surprisingly, barley grain from plants which had been checked by combine-drilled 14-6-8 contained no more $\mathrm{N}$ than grain from plants where the 14-6-8 had been injected and hence was harmless. Presumably therefore uptake of $\mathrm{N}$ from each was delayed and so the nitrogen behaved as if it had been applied at a later date. Whether this was because the banded $\mathrm{N}$ was less accessible physically to the roots, or whether the urea in it nitrified more slowly because of its concentration in the band we cannot tell.

Table 6 shows that the barley removed as much $\mathrm{N}$ from $63 \mathrm{~kg} \mathrm{~N} /$ ha given in liquid as in granular form and that removal differed little with method of application. However, when $126 \mathrm{~kg} \mathrm{~N} / \mathrm{ha}$ was given, nitrogen uptake was altered by method of application, for the losses in yield of grain from combine-drilling the 14-6-8 and the smaller percentages of $\mathrm{N}$ in the grain from spraying it, were reflected in smaller total uptakes. Values from the other treatments were similar to those from granules.

\section{DISCUSSION AND CONCLUSIONS}

The technique of injecting nitrogen fertilizer with a cultivator drill whilst the seed bed was being prepared produced no outstanding advantage, though yields from $\mathbf{N}$ applied in this way tended to be a little larger than where $\mathrm{N}$ had been broadcast. Surprisingly, the gains from injecting urea were similar to and no greater than those from injecting 'Nitro-Chalk', though surface dressings of urea are sometimes subject to losses of ammonia by evaporation. Evidently sizeable increases in yield 
cannot be expected from adopting this technique under our conditions, though no loss will be suffered if there are organizational advantages from adopting this practice on the farm.

The experiments with liquid fertilizers confirmed that those rich in urea should not be combine. drilled, but showed that these could safely be injected mid-way between rows of barley that were $15 \mathrm{~cm}$ apart. A liquid fertilizer supplying the same amounts of $\mathrm{P}$ and $\mathrm{K}$, but only one-fifth of the $\mathrm{N}$ (and hence little urea), did no harm when it was combine-drilled, but greatly enhanced early growth on some calcareous soils which had been used to grow long runs of cereals. This benefit did not occur when the same fertilizer was injected between the rows of barley. Our conclusion is, therefore, that those farmers who grow barley on soils that contain little available phosphorus and who intend to use liquid fertilizers in future, should adapt their seed drills so that an NPK fertilizer supplying the whole of the $\mathrm{P}$ and $\mathrm{K}$ and a little of the $\mathrm{N}$ can be pumped down the rear of the seed coulter and so in contact with the seed. The remainder of the $\mathrm{N}$ should be applied at the most appropriate time, depending on the date of sowing, the kind of soil and the risk of leaching. There seems little purpose in adding additional coulters or tines to drills, so that liquids rich in urea can be injected between the seeds rows (and hence supply all the $\mathbf{N}$ ) without risk, because in our experiments sprayed dressings were equally as effective. The fact that early sown spring barley generally outyields the late, especially on the lighter soils, pro. vides an additional argument for split applications of nitrogen. For the only soils that consistently allow early sowing are the free draining ones where seed-bed $\mathrm{N}$ is at greatest risk from leaching.

We thank J.H. A. Dunwoody for statistical analyses, D. M. Ramsay for help with the trials rig, R. C. Flint, V. Cosimini and other members of the Rothamsted staff who helped with the experiments and the farmers who provided the sites for their sustaining interest.

\section{REFERENCES}

Kahari, J. \& Elonin, P. (1969). Effect of placement of fertiliser and sprinkler irrigation on the development of spring cereals on the basis of root investigations. Journal of the Scientific Agricultural Society of Finland 41, 89-104.

Dam Kofoed, A. \& Larsen, K. E. (1971). Comparisons between different field practices of applying solid urea. Saertrylo af Tidsskrift for Plantearl 75, 549-54.
Widdowson, F. V., Penny, A. Flint, R. C. (1972). Results from barloy experiments comparing aqueous ammonia and aqueous urea with ammonium nitrate, and also liquid with granular NPK fertilizers. Journal of Agricultural Science, Cambridge 79, 349-61. 
Appendix Table 1. Yields of grain (t/ha at $85 \%$ D.M.) from barley experiments comparing ' Nitro-Chalk' with urea, when each was either injected into, or broadcast over the final seed bed, 1969-71

Location $\ldots$

Year

Mothod ...

Without nitrogen

s.E.

With $63 \mathrm{~kg} \mathrm{~N} / \mathrm{ha}$ as

'Nitro-Chalk'

Aqua urea

With $126 \mathrm{~kg} \mathrm{~N} / \mathrm{ha}$ as

'Nitro-Chalk'

Urea

Aqua urea

S.E. of a difference
Rothamsted

$\overbrace{\text { Broad- In- }}^{1969} \overbrace{\text { Broad- In- }}^{1970} \overbrace{\text { Broad- In- }}^{1971}$
cast jected cast jected cast jected

$$
4.57
$$$$
\pm 0 \cdot 128
$$

$\begin{array}{ll}5.85 & 6.0 \\ 6.11 & 6.14\end{array}$

$6.11 \quad 6 \cdot 14$

$4 \cdot 28$

$4 \cdot 28$
$4 \cdot 23$

$-77$

$5 \cdot 77 \quad 5 \cdot 97$

$\mathbf{5} \cdot 80 \quad \mathbf{5} \cdot \mathbf{9 0}$

- 0181

$\begin{array}{cc}- & - \\ 4.53 & 4.63 \\ 4.48 & 4.49 \\ - & -\end{array}$

$$
2 \cdot 33
$$$$
\pm 0.078
$$

$4 \cdot 28 \quad 4 \cdot 33$

$4 \cdot 25$

3.99
\pm 0.069

$5.60 \quad 5 \cdot 75$

$\begin{array}{ll}5 \cdot 60 & \mathbf{5} \cdot 75 \\ 5 \cdot 83 & \mathbf{5} \cdot 73\end{array}$

$5 \cdot 73 \quad 5 \cdot 76$

$6 \cdot 10 \quad 6 \cdot 27$

$6 \cdot 26 \quad 6 \cdot 25$

$6 \cdot 23 \quad 6 \cdot 26$

$\pm 0 \cdot 110$

$\pm 0 \cdot 138$
Woburn

$\overbrace{\text { Broad. In- }}^{1969} \overbrace{\text { Broad- In- }}^{1970} \overbrace{\text { Broad. In- }}^{1971}$

jected cast jected cast jected

$\begin{array}{lrr}1.26 & 3.70 & 5.80\end{array}$

$\pm 0 \cdot 151$

$\pm 0 \cdot 238$

$\pm 0 \cdot 118$

$\begin{array}{llllll}3 \cdot 79 & 3 \cdot 90 & 5 \cdot 25 & 4 \cdot 98 & 5 \cdot 82 & 6 \cdot 07 \\ 3 \cdot 78 & 4 \cdot 24 & 4 \cdot 71 & 5 \cdot 07 & 6 \cdot 10 & 6 \cdot 32\end{array}$

一 $\quad-\quad$ - $\quad$ - $5.88 \quad 5.88$

$\begin{array}{llllll}4.35 & 4 \cdot 64 & 4.83 & 4.92 & 5.47 & 5 \cdot 60\end{array}$

$\begin{array}{llllll}4 \cdot 44 & 4 \cdot 67 & 4 \cdot 78 & 4 \cdot 67 & 5 \cdot 62 & 5 \cdot 40\end{array}$

- $\quad-\quad-\quad 5 \cdot 61 \quad 5 \cdot 48$

$\pm 0.214 \quad \pm 0.336 \quad \pm 0 \cdot 235$

Appendix Table 2. The percentages of $N$ in barley grain from experiments comparing 'Nitro-Chalk' with urea, when each was either injected into, or broadcast over the final seed bed, 1969-71

Location ...

Year $\quad$...

Mothod ...

Without nitrogen

s.E.

With $63 \mathrm{~kg} \mathrm{~N} / \mathrm{ha}$ as

'Nitro-Chalk'
Urea

Aqua urea

With $126 \mathrm{~kg} \mathrm{~N} / \mathrm{ha}$ as

'Nitro.Chalk'

Aqua urea

S.E. of a difference
Rothamsted

$\overbrace{\text { road. In- In }}^{1969} \overbrace{\text { Broad. }}^{1970} \overbrace{\text { In- }}^{1971} \overbrace{\text { Broad. }}^{197 .}$

cast jected cast jected cast jected

$$
1 \cdot 36
$$$$
\pm 0.035
$$

$$
1.58
$$$$
\pm 0.040
$$

$1 \cdot 31 \quad 1.38$

$1.38 \quad 1 \cdot 32$

$1 \cdot 70$

\begin{tabular}{llll}
1.70 & 1.68 & 1.38 & 1.40 \\
1.68 & 1.71 & 1.44 & 1.39 \\
\hline
\end{tabular}

168

$1 \cdot 7$

$1 \cdot 44$

$1 \cdot 32$

$\pm 0 \cdot 031$

$\begin{array}{ll}1.64 & 1.67 \\ 1.66 & 1.72\end{array}$

$2 \cdot 10 \quad 2 \cdot 10$

$1 \cdot 63 \quad 1.48$

$\begin{array}{llll}2.03 & 2.00 & 1.60 & 1.54\end{array}$

$1.56 \quad 1.61$

$\pm 0.062$

\begin{tabular}{|c|c|c|}
\hline 1969 & 1970 & 1971 \\
\hline
\end{tabular}

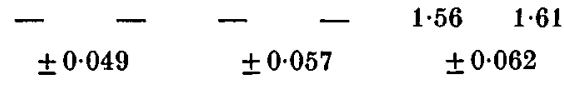

$\pm 0.057$
Woburn

cast jected cast jected cast jected

$$
1 \cdot 28
$$

$\pm 0 \cdot 049$

1.65

$\pm 0 \cdot 040$

$1 \cdot 70$

$\pm 0.038$

$\begin{array}{llllll}1.15 & 1.12 & 1.77 & 1.92 & 1.90 & 1.81\end{array}$

\begin{tabular}{llllll}
1.15 & 1.28 & 1.97 & 1.86 & 1.81 & 1.78 \\
\hline
\end{tabular}

- $-\quad-\quad-\quad 1.91 \quad 1.76$

$\begin{array}{llllll}1.82 & 1.66 & 2 \cdot 15 & 2 \cdot 12 & 2.04 & 2 \cdot 13\end{array}$

$\begin{array}{llllll}1.58 & 1.71 & 2.18 & 2.15 & 1.94 & 2.15\end{array}$

一 - - — - $2.07 \quad 2.04$

$\pm 0.069 \quad \pm 0.057$

$\pm 0.076$ 


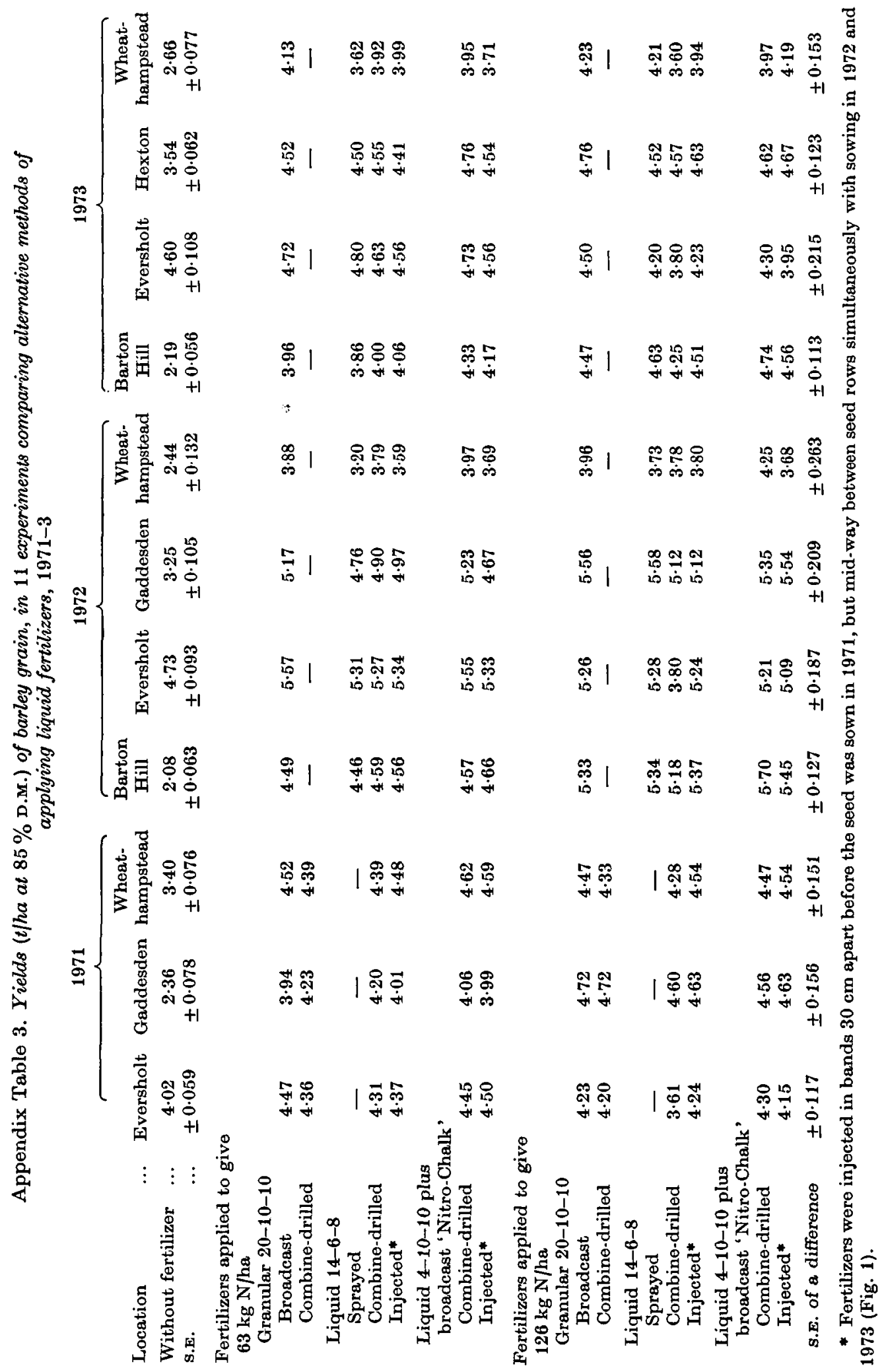


Injecting solid and liquid fertilizers for barley

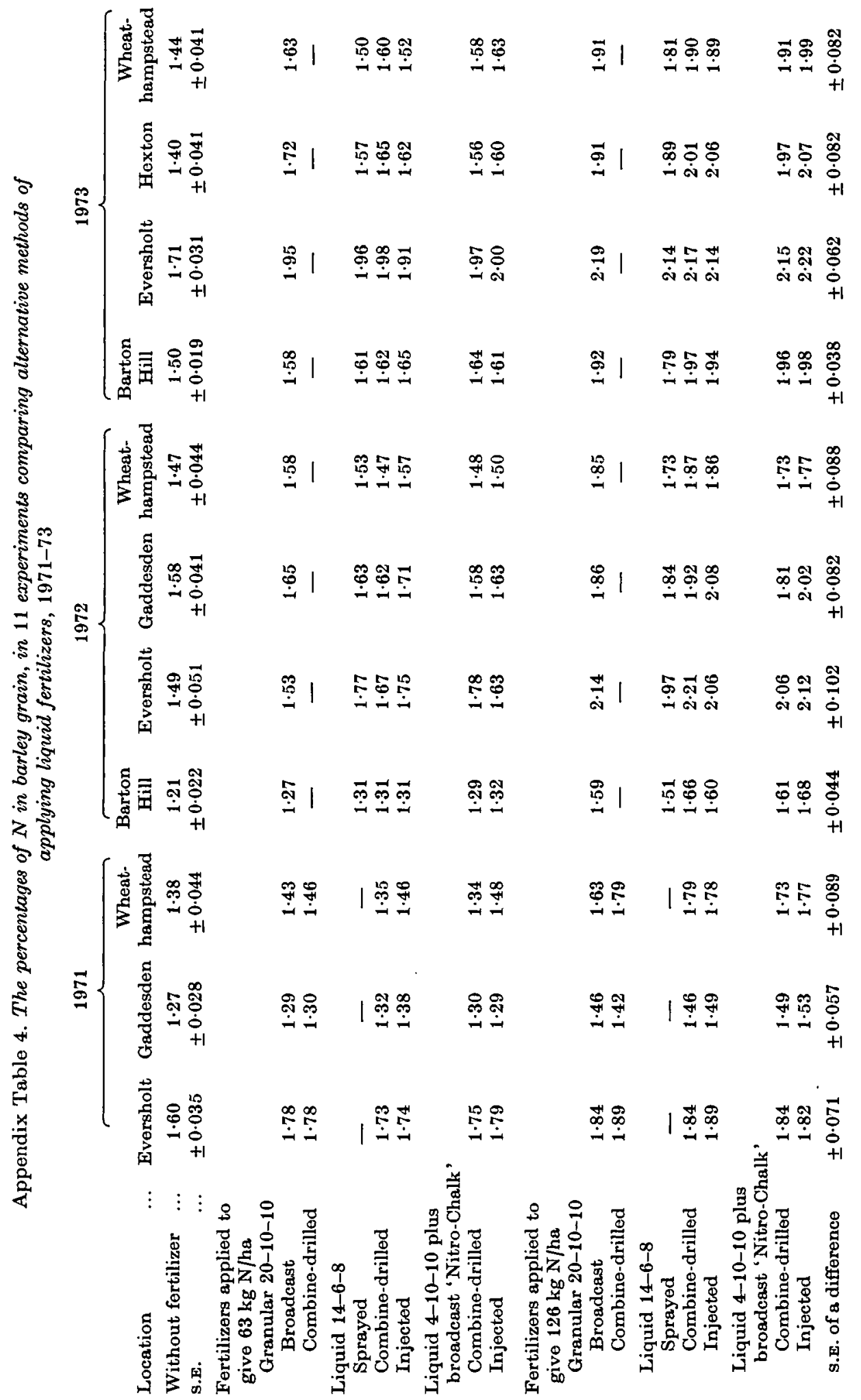

